\title{
Primary Epithelioid Sarcoma Manifesting as a Fungating Scalp Mass - Imaging Features and Treatment Options. A Case Report and Literature Review
}

\author{
Yonghao Zhang ${ }^{1 *}$, Tarun Mohan Mirpuri ${ }^{1}$, Chi Long $\mathrm{Ho}^{1,2,3,4}$ \\ 1. Department of Radiology, Sengkang General Hospital, Singapore \\ 2. Duke-NUS Medical School, Singapore \\ 3. Yong Loo Lin School of Medicine, National University of Singapore, Singapore \\ 4. Lee Kong Chian School of Medicine, Nanyang Technological University, Singapore \\ * Correspondence: Yonghao Zhang,110 Sengkang East Way, Singapore 544886, Singapore \\ (入zhangyonghao123@hotmail.com)
}

Radiology Case. 2021 Nov; 15(11):1-9 $\quad:: \quad$ DOI: $10.3941 /$ jrcr.v15i11.4326

\begin{abstract}
Primary epithelioid sarcoma is an extremely rare malignancy of the scalp. To date, less than a dozen such cases have been reported in the literature. The diagnosis often is a challenge to both radiologists and clinicians. This is largely attributed to the lack of literature on the imaging features of scalp epithelioid sarcoma. In this report, we highlight the role of multimodality imaging in the diagnosis of primary scalp epithelioid sarcoma and review the epidemiology, imaging, treatment options, and prognosis of these malignant scalp tumors. Displaying a multilobulated morphology, heterogeneous enhancement, and restricted diffusion on MRI, these tumors typically show central degeneration with hemorrhage, necrosis, and calcification. Wide surgical resection and adjuvant radiotherapy are the mainstays of treatment for localized scalp tumors. Nevertheless, the prognosis of patients with distant metastases at diagnosis is extremely poor compared to those with local or regional diseases.
\end{abstract}

\section{CASE REPORT}

\section{CASE REPORT}

A 67-year-old man was referred to the emergency department by the general practitioner for a painful growth on his scalp over the past month. Apart from a history of cognitive impairment, he was otherwise well. Physical examination revealed a large pedunculated fungating mass on his right parietal scalp region. Assessment of the skin and the rest of the systemic physical review were unremarkable. The laboratory and blood tests were also unremarkable.

An initial CT brain revealed a large lobulated $10 \times 5 \times 5$ $\mathrm{cm}$ soft tissue mass arising from the right parietal scalp with peripheral calcification and patchy post-contrast enhancement 
(Figure 1). Besides areas of calcification and necrosis in the scalp mass, there was no erosion of the underlying calvarium nor involvement of the underlying dura or brain parenchyma. Subsequently, contrast-enhanced magnetic resonance imaging (MRI) brain with time-of-flight (TOF) magnetic resonance angiogram (MRA) was performed to further characterize the mass and delineate the extent of disease. Moreover, this could explore the option of preoperative embolization of any feeding vessels to the vascularized tumor. The MR examinations revealed an avidly enhancing central vascularized pedicle within the soft tissue mass with branches supplying peripheral hemorrhagic components of the mass and the skin (Figure 2AB). Diffusion-weighted imaging (DWI) and Apparent diffusion coefficient (ADC) images revealed restricted diffusion within the "stalk" of the mass (Figure 2C-D). There was peripheral blood supply to the soft tissue mass from branches of the right superficial temporal and right occipital arteries on the TOF MRA (Figure 2E).

An incisional biopsy of the scalp tumor was performed, and the histology revealed a high-grade malignant epithelioid sarcoma. Subsequent whole-body screening CT study showed no evidence of a primary malignancy nor distant metastases. Eventually, a wide excision of the scalp tumor with subsequent split skin graft was performed. The histology of the resected tumor specimen revealed surface ulceration with mixed inflammatory cell infiltration. Post-operative surveillance was unremarkable with no evidence of tumor recurrence at 36 months.

\section{DISCUSSION}

\section{Etiology \& Demographics:}

Epithelioid sarcoma (ES) is a rare type of malignant soft tissue tumor arising from mesenchymal tissue and epithelial cells [1]. It constitutes less than $1 \%$ of all soft tissue sarcomas [2]. ES was first described and established as a distinct clinicopathological entity by Enzinger in 1970 [1]. In the WHO classification, it is classified under malignant tumors of uncertain differentiation [3].

The etiology is largely unknown, though the loss of expression of tumour suppression gene INI1 (SMARCB1) has been implicated in $90 \%$ of patients with ES [4]. An association with prior local trauma has been reported in $27 \%$ of the cases [3].

The incidence of ES has been increasing with an incremental annual percentage change of $5.2 \%$ since 1973 , with the overall incidence reported as 0.04 per 100,000 persons in the United States in 2005 [5]. This tumor is typically located in the extremities, and it can be subdivided into two categories: distal and proximal variants [6]. Proximal ES often affects the truncal soft tissues, thighs, and head and neck. Distal ES typically involves the distal extremities of young adults. Primary ES of the scalp is very rare, accounting for only $3.2 \%$ of all ES cases [3]. The male-to-female ratio is approximately 1.8:1. It affects patients between 1 and 80 years with a peak incidence at 75 years of age $[3,4]$.
Scalp ES is correlated with a poor prognosis and all relapsed cases exhibited bone erosion [3]. Necrosis exists in up to $70 \%$ of the cases and is usually associated with central degeneration [6]. Most cases exhibit a dominant epithelioid morphology in the dermis and subcutaneous tissues with ulcer and lymphovascular invasion; occasionally, granuloma-like features, calcification and bone formation may occur $[3,4]$.

To date, only 11 cases of scalp ES have been reported in the literature, including our case [6]. The clinical and pathological features of published cases and our present case are summarized in Table 3. In the prior reports, there was a lack of data on its characteristic imaging features allowing ES to be differentiated from other malignant scalp tumors. Besides reviewing the epidemiology, we seek to highlight the characteristic imaging features of the current case, treatment options and the prognosis related to primary scalp ES.

\section{Imaging findings:}

The diagnosis of ES of the scalp often poses a challenge to both radiologists and clinicians because of the vast etiologies and varied radiological appearances of scalp tumors [7]. Multimodality imaging is employed in narrowing down the differential diagnoses of scalp masses, as well as in distinguishing malignant from benign scalp masses. Furthermore, imaging can evaluate the extent of local tumor invasion, stage disease and guide surgical biopsy and/or tumor resection [6].

The varied radiological appearances of ES are largely dependent on the wide-ranging histological morphologies of the tumor $[8,9]$. The rate of correct pre-operative diagnosis was found to be as low as $13 \%$ [10]. It has been suggested that the multilobulated radiological morphology and the irregular and often ill-defined borders of ES may be used to differentiate ES from other soft-tissue sarcomas, though these characteristics may not be evident in smaller tumors [8]. Among all the previously reported scalp ES cases in the literature, the present fungating scalp mass is shown to be the largest in terms of size (Table 3). Besides having a multilobulated shape, primary scalp ES shows central degeneration with hemorrhage, necrosis, and calcification (Figure 1). On MRI, the mass reveals central areas of restricted diffusion with avid contrast enhancement. There are peripheral areas of mixed MR signal intensity due to hemorrhage, necrosis, and calcification. Tumor vascularity and blood supply can be assessed using MR or CT angiogram. There is often a vascular pedicle detected within the mass with blood supply from branches of the external carotid artery, particularly branches of the superficial temporal and middle meningeal arteries. These imaging features, although not particularly specific, may be present in up to $70 \%$ of primary scalp ES [6].

\section{Treatment \& Prognosis:}

Wide surgical resection and adjuvant radiotherapy is the mainstay of treatment for localized or scalp ES [6]. Presurgical embolization can be helpful to reduce tumor vascularity and neo-adjuvant or adjuvant radiotherapy is useful to reduce local recurrence rate [11] 
Compared to primary ES affecting other locations, ES of the scalp, however, has a greater tendency for local recurrence, with a 5-year recurrence rate of 35\% [6]. Being an aggressive and infiltrative soft tissue sarcoma, ES has the propensity to spread early via vascular and/ or lymphatic routes. About $50 \%$ of patients develop distant metastases, especially to the lungs, regional lymph nodes, and bones. Furthermore, hemorrhagic ES has been suggested to be at a higher risk of distant metastasis compared to non-hemorrhagic tumors [12]. PET/CT has been superior to other imaging modalities in the detection of distant metastases [6].

Patients with distant metastases have a poor prognosis with expected median overall survival of about one year, though these patients may be amenable to palliative treatment with Doxorubicin-based regimens [13]. Patients diagnosed with a local disease have a better 5-year survival of $75 \%$ as compared to those with a regional disease with a 5-year survival of $49 \%$ [5]. Distant metastasis at the time of diagnosis is widely accepted as a predictor of a worse prognosis. None of the patients who presented with distant disease survived for 5 years, while 1-year survival is estimated at $46 \%$. Ross et al. reported no association of the primary site of the tumor with patient survival [14]. No survival advantage is associated with any gender, race, or ethnic group [5].

\section{Differential diagnoses:}

Based on the morphology and MRI appearance of the current scalp ES, the differential diagnosis (DD) includes other malignant mesenchymal neoplasms of the scalp including angiosarcoma, adult-type fibrosarcoma (AFS), leiomyosarcoma, malignant peripheral nerve sheath tumor (MPNST), and malignant proliferating trichilemmal tumor (MPTT). Poorly differentiated squamous cell carcinoma (SCCA) must be added to the DD panel given its overlapping pathological similarities with ES.

\section{Angiosarcoma}

Angiosarcomas account for $2 \%$ of all adult sarcomas. It usually affects men between 55-70 years of age [15]. These tumors originate from the endothelial cells of blood vessels or lymphatics. On MRI, angiosarcomas typically demonstrate local infiltration of the subcutaneous tissue and muscles of the scalp. They may contain areas of necrosis and serpiginous vessels due to high tumor vascularity. Having a central vascular pedicle, similar to ES, angiosarcomas have a propensity to hemorrhage. Being highly aggressive, they have a high rate of local recurrence even after wide surgical resection [16]. Furthermore, they tend to have multifocal and hematogenous dissemination, particularly to the lungs [15].

\section{Adult-type fibrosarcoma (AFS)}

AFS represents $1-3 \%$ of all reported sarcoma cases [17]. It is more common in males than in females and usually presents between the ages of 30 and 55 years. These are painless and slow-growing tumors that often occur in the extremities, trunk, and pelvis, and rarely occur in the retroperitoneum, mediastinum, head, or neck [18]. These are highly vascularized tumors with well-defined borders but often manifest local ulceration and hemorrhage. Advanced cases may show necrosis, degeneration, and bony erosion [19]. Histologically, AFS typically demonstrate V-shaped bundle formation and a herringbone pattern [20]. MRI typically shows $\mathrm{T} 1$ and $\mathrm{T} 2$ inhomogeneity (often $\mathrm{T} 1$ iso- to hypointense and T2 hyperintense) with peripheral contrast enhancement. Hematogenous spread of metastases to the lungs and axial skeleton has been reported in $9-63 \%$ of AFS cases [18].

\section{Leiomyosarcoma (LMS)}

Primary LMS accounts for $2-3 \%$ of all soft-tissue sarcomas and commonly affects men between 40-60 years of age $[21,22]$. LMS is classified as cutaneous or subcutaneous, based on its location of origin in the scalp [23]. They are often seen as solitary, well-defined nodules measuring up to $6 \mathrm{~cm}$ in post-traumatic or sun-exposed skin. Compared to smaller cutaneous subtypes, larger subcutaneous subtypes of LMS arise primarily from the smooth muscle layer of vessel walls and grow rapidly [22, 23]. Furthermore, the subcutaneous subtype has the highest rate of local recurrence (50-70\%) and distant metastasis (30-40\%) [23]. Intratumor necrosis and calcification can be detected on imaging.

\section{Malignant peripheral nerve sheath tumor (MPNST)}

MPNST is a rare and aggressive malignancy that accounts for $5-10 \%$ of all soft tissue sarcomas with only about $8-16 \%$ occurring in the head and neck region [24]. Up to $50 \%$ of MPNST occurs in patients with neurofibromatosis type-1 (NF1 ), while de novo cases usually result from malignant transformation of a pre-existing plexiform neurofibroma [25].

\section{Malignant proliferating trichilemmal tumor (MPTT)}

Proliferating trichilemmal tumor (PTT) is an uncommon benign lesion, which may be misdiagnosed as squamous cell carcinoma. It is also known as proliferating trichilemmal cyst and pilar tumor of the scalp [26]. Although $90 \%$ of PTTs occur on the scalp, they have also been found on the chest, abdomen, buttocks, upper extremities, and vulva [27]. Malignant transformation of PTT (MPTT) usually presents between the ages of 60 and 70 years, affecting women in $80 \%$ of cases with an age range from 27 to 83 years [26]. Although MPTTs is known for its slow growth with long disease duration, it may become malignant when the cell growth rate increases, at which point the tumor surface ulcerates, bleeds and exhibits necrosis. These tumors recur and metastasize more frequently than squamous cell carcinoma and ES.

On MRI, these tumors are T1 isointense and T2 hyperintense relative to muscle. Contrast-enhanced CT shows a large, well-encapsulated, cystic mass predominantly in the subcutaneous layer [28]. These tumors have well-enhancing walls of variable thickness which contain multiple speckled calcifications and several foci of smooth soft-tissue elevations arising from its inner walls.

\section{Squamous cell carcinomas (SCCA)}

These are the second most common skin malignancies after basal cell carcinomas (BCCA) however, SCCA are more aggressive and have a higher propensity to metastasize [29]. Around 3-8\% of SCCAs are located in the scalp, and they have a greater tendency to ulcerate. SCCs of the scalp often present with chronic, non-healing ulceration which can partially attribute to their late diagnosis. As they are often diagnosed at an advanced stage, they have a greater propensity to invade and recur. 


\section{Conclusion}

Being an aggressive and infiltrative soft tissue sarcoma, primary scalp ES has the propensity to spread early, usually via hematogenous or lymphatic routes. Patients with distant metastasis portend a worse prognosis compared to those with local or regional disease. Therefore, early and accurate diagnosis and prompt initiation of treatment are paramount in patient management.

\section{TEACHING POINT}

Knowledge of MRI helps narrow the diagnosis of malignant scalp masses; the presence of a vascular pedicle supplying the fungating scalp mass distinguishes epithelioid sarcoma from other scalp malignancies. Presurgical embolization followed by wide surgical resection and adjuvant radiotherapy are the mainstay treatment for localized scalp epithelioid sarcoma. Distant metastasis portends a worse prognosis compared to local or regional disease hence accurate diagnosis and prompt treatment are paramount in patient management.

\section{REFERENCES}

1. Enzinger FM. Epitheloid sarcoma. A sarcoma simulating a granuloma or a carcinoma. Cancer. 1970;26(5):1029-41. PMID: 5476785

2. de Visscher SA, van Ginkel RJ, Wobbes T, et al. Epithelioid sarcoma: Still an only surgically curable disease. Cancer. 2006;107(3):606-12. PMID: 16804932

3. Fisher C. Epithelioid sarcoma of Enzinger. Adv Anat Pathol. 2006;13(3):114-21. PMID: 16778474

4. Hollmann TJ, Hornick JL. INI1-deficient tumors: diagnostic features and molecular genetics. Am J Surg Pathol. 2011;35(10):e47-63. PMID: 21934399

5. Jawad MU, Extein J, Min ES, Scully SP. Prognostic factors for survival in patients with epithelioid sarcoma: 441 cases from the SEER database. Clinical orthopaedics and related research. 2009;467(11):2939-2948. PMID: 19224301

6. Zhang X-W, Deng Y-J, Zhou L, Deng H. Epithelioid sarcoma of the scalp: a case report and literature review. International journal of clinical and experimental pathology. 2019;12(10):3908-3914. PMID: 31933781

7. Kawaguchi M, Kato H, Matsuo M. CT and MRI features of scalp lesions. Radiol Med. 2019;124(10):1049-1061. PMID: 31270724

8. Tateishi U, Hasegawa T, Kusumoto M, Yokoyama R, Moriyama N. Radiologic Manifestations of Proximal-Type Epithelioid Sarcoma of the Soft Tissues. American Journal of Roentgenology 2002;179(4):973-977. PMID: 12239049

9. Kim YS, Kwak HS, Chung GH, Kim YN, Hwang S. Epithelioid sarcoma arising from the temporal space: A case report. Medicine (Baltimore) 2018;97(38):e12529-e12529. PMID: 30235775
10. Türk C, Bacanli A, Kara NN. Incidence and clinical significance of lesions presenting as a scalp mass in adult patients. Acta Neurochir (Wien) 2015;157(2):217-23. PMID: 25380646

11. Dangoor A, Seddon B, Gerrand C, Grimer R, Whelan J, Judson I. UK guidelines for the management of soft tissue sarcomas. Clin Sarcoma Res. 2016;6:20. PMID: 27891213

12. Romero JA, Kim EE, Moral IS. MR characteristics of epithelioid sarcoma. J Comput Assist Tomogr.1994;18(6):92931. PMID: 7962802

13. Czarnecka AM, Sobczuk P, Kostrzanowski M, Spalek M, Chojnacka M, Szumera-Cieckiewicz A, et al. Epithelioid Sarcoma-From Genetics to Clinical Practice. Cancers (Basel) 2020;12(8). PMID: 32751241

14. Ross HM, Lewis JJ, Woodruff JM, Brennan MF. Epithelioid sarcoma: clinical behavior and prognostic factors of survival. Ann Surg Oncol. 1994;4(6):491-5. PMID: 9309338

15. Coindre JM, Terrier P, Guillou L, Le Doussal V, Collin F, Ranchère $\mathrm{D}$, et al. Predictive value of grade for metastasis development in the main histologic types of adult soft tissue sarcomas: a study of 1240 patients from the French Federation of Cancer Centers Sarcoma Group. Cancer 2001;91(10):191426. PMID: 11346874

16. Kruse-Lösler B, Presser D, Meyer U, Schul C, Luger T, Joos U. Reconstruction of large defects on the scalp and forehead as an interdisciplinary challenge: experience in the management of 39 cases. Eur J Surg Oncol. 2006;32(9):100614. PMID: 16806795

17. Angiero F, Rizzuti T, Crippa R, Stefani M. Fibrosarcoma of the jaws: two cases of primary tumors with intraosseous growth. Anticancer Res. 2007;27(4c):2573-81. PMID: 17695417

18. Fisher C, van den Berg E, Molenaar WM. Adult Fibrosarcoma. In: Fletcher CDM, Unni KK, Mertens F, editors. Pathology and Genetics of Tumours of Soft Tissue and Bone. 10-18. IARC Press. Lyon 2002.

19. Toro JR, Travis LB, Wu HJ, Zhu K, Fletcher CD, Devesa SS. Incidence patterns of soft tissue sarcomas, regardless of primary site, in the surveillance, epidemiology and end results program, 1978-2001: An analysis of 26,758 cases. Int $\mathbf{J}$ Cancer. 2006;119(12):2922-30. PMID: 17013893

20. Guillou L FA. Fibroblastic and Fibrohistiocytic Tumors. In: Bone and Soft Tissue Pathology. IC Folpe AL. Philadelphia, PA; Elsevier 2010;63-64. ISBN: 9780443066887

21. Agale S, Grover S, Zode R, Hande S. Primary cutaneous leiomysarcoma. Indian journal of dermatology 2011;56(6):728-30. PMID: 22345781 
22. Massi D, Franchi A, Alos L, Cook M, Di Palma S, Enguita $\mathrm{AB}$, et al. Primary cutaneous leiomyosarcoma: clinicopathological analysis of 36 cases. Histopathology 2010;56(2):251-62. PMID: 20102404

23. Angeloni M, Muratori F, Magarelli N, Chalidis BE, Ricci R, Rossi B, et al. Exophytic growth of a neglected giant subcutaneous Leiomyosarcoma of the lower extremity. A case report. International Seminars in Surgical Oncology 2008;5(1):11. PMID: 18495007

24. Ralli M, Singh S, Hasija S, Verma R. Intrathoracic Malignant Peripheral Nerve Sheath Tumor: Histopathological and Immunohistochemical Features. Iran $\mathbf{J}$ Pathol. 2015;10(1):74-8. PMID: 26516330

25. Farid M, Demicco EG, Garcia R, Ahn L, Merola PR, Cioffi A, et al. Malignant peripheral nerve sheath tumors. Oncologist 2014;19(2):193-201. PMID: 24470531

26. Janitz J, Wiedersberg H. Trichilemmal pilar tumors. Cancer 1980;45(7):1594-7. PMID: 7370918

27. Markal N, Kurtay A, Velidedeoglu H, Hücümenoglu S. Malignant Transformation of a Giant Proliferating Trichilemmal Tumor of the Scalp: Patient Report and Literature Review. Annals of Plastic Surgery 2008;41(3):3146. PMID: 9746092

28. Kim HJ, Kim TS, Lee KH, Kim YM, Suh $\mathrm{CH}$. Proliferating trichilemmal tumors: $\mathrm{CT}$ and $\mathrm{MR}$ imaging findings in two cases, one with malignant transformation. AJNR Am J Neuroradiol. 2001;22(1):180-3. PMID: 11158906
29. Andrade P, Brites MM, Vieira R, Mariano A, Reis JP, Tellechea $\mathrm{O}$, et al. Epidemiology of basal cell carcinomas and squamous cell carcinomas in a Department of Dermatology: a 5 year review. An Bras Dermatol. 2012;87(2):212-9. PMID: 22570024

30. Gurwale S, Gore C, Kaur S, Deshpande A. Primary epithelioid sarcoma of scalp. Asian Journal of Oncology 2017; 3: 71-73. DOI: 10.4103/ASJO.ASJO_113_16

31. Tocco I, Bassetto F, Vindigni V. Primary epithelioid sarcoma of the scalp complicated by humoral hypercalcemia of malignancy. Eplasty 2012; 12: ic18. PMID: 23359842

32. Hanna SL, Kaste S, Jenkins JJ, Hewan-Lowe K, Spence JV, Gupta M, et al. Epithelioid sarcoma: clinical, MR imaging and pathologic findings. Skeletal Radiol 2002; 31: 400-412. PMID: 12107573

33. Suwantemee C. Primary epithelioid sarcoma of the scalp. Plast Reconstr Surg 1999; 104: 785-8. PMID: 10456531

34. Skoog L, Pereira ST, Tani E. Fine-needle aspiration cytology and immunocytochemistry of soft-tissue tumors and osteo/chondrosarcomas of the head and neck. Diagn Cytopathol 1999; 20: 131-136. PMID: 10086236

35. Gross E, Rao BN, Pappo A, Bowman L, Shearer P, Kaste S, et al. Epithelioid sarcoma in children. J Pediatr Surg 1996; 31: 1663-5. PMID: 8986982

36. Kodet R, Smelhaus V, Newton WA Jr, et al. Epithelioid sarcoma in childhood: an immunohistochemical, electron microscopic, and clinicopathologic study of 11 cases under 15 years of age and review of the literature. Pediatr Pathol 1994; 14: 433-451. PMID: 7520581.
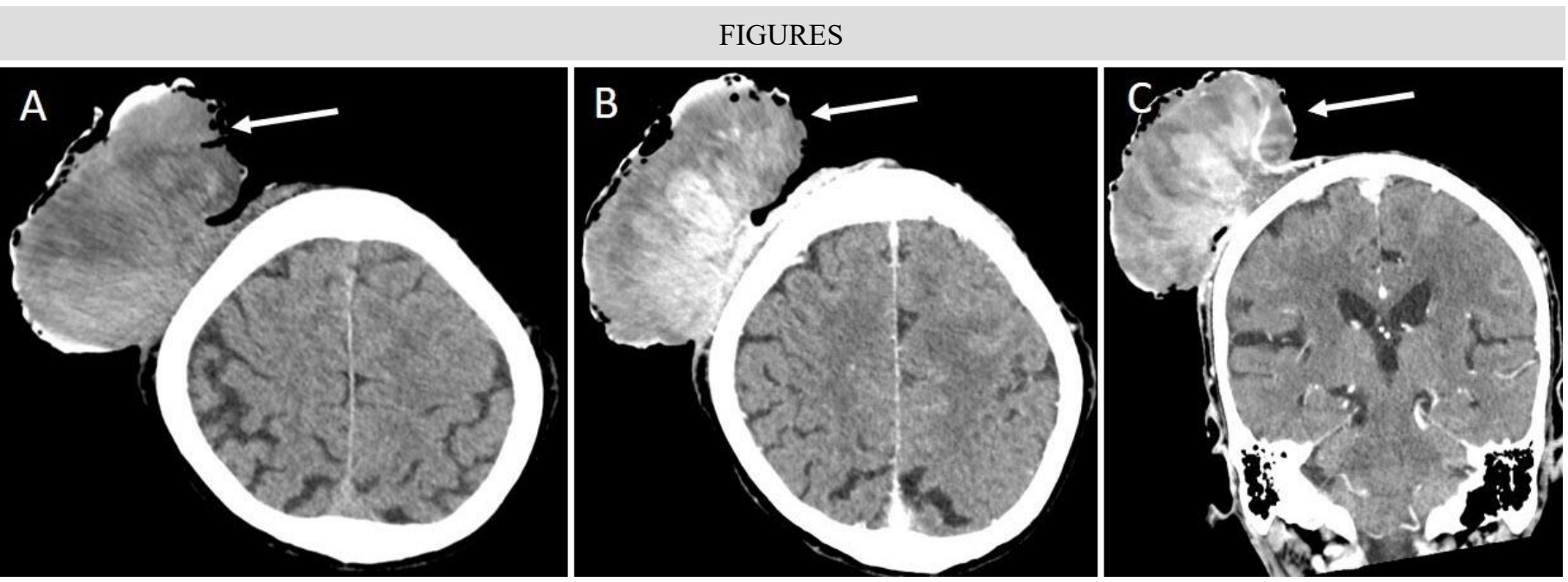

Figure 1: A 67-year-old man with a right parietal scalp tumor with histologically proven epithelioid sarcoma.

FINDINGS: Non-enhanced axial (A), and contrast-enhanced computed tomography (CECT) in axial (B) and coronal (C) planes demonstrate a large heterogeneously enhancing "mushroom" shaped soft tissue mass arising from the right parietal scalp region without the involvement of the underlying skull bone or brain. There are areas of calcification, enhancement and necrosis within the mass (arrows).

TECHNIQUE: Non-enhanced CT and CECT of a 67-year-old man in axial and coronal planes. GE Medical System Revolution. Slice width $=3.12 \mathrm{~mm}$. Intravenous contrast $=$ Omnipaque 350 . Total amount contrast administered $=50 \mathrm{ml}$. 

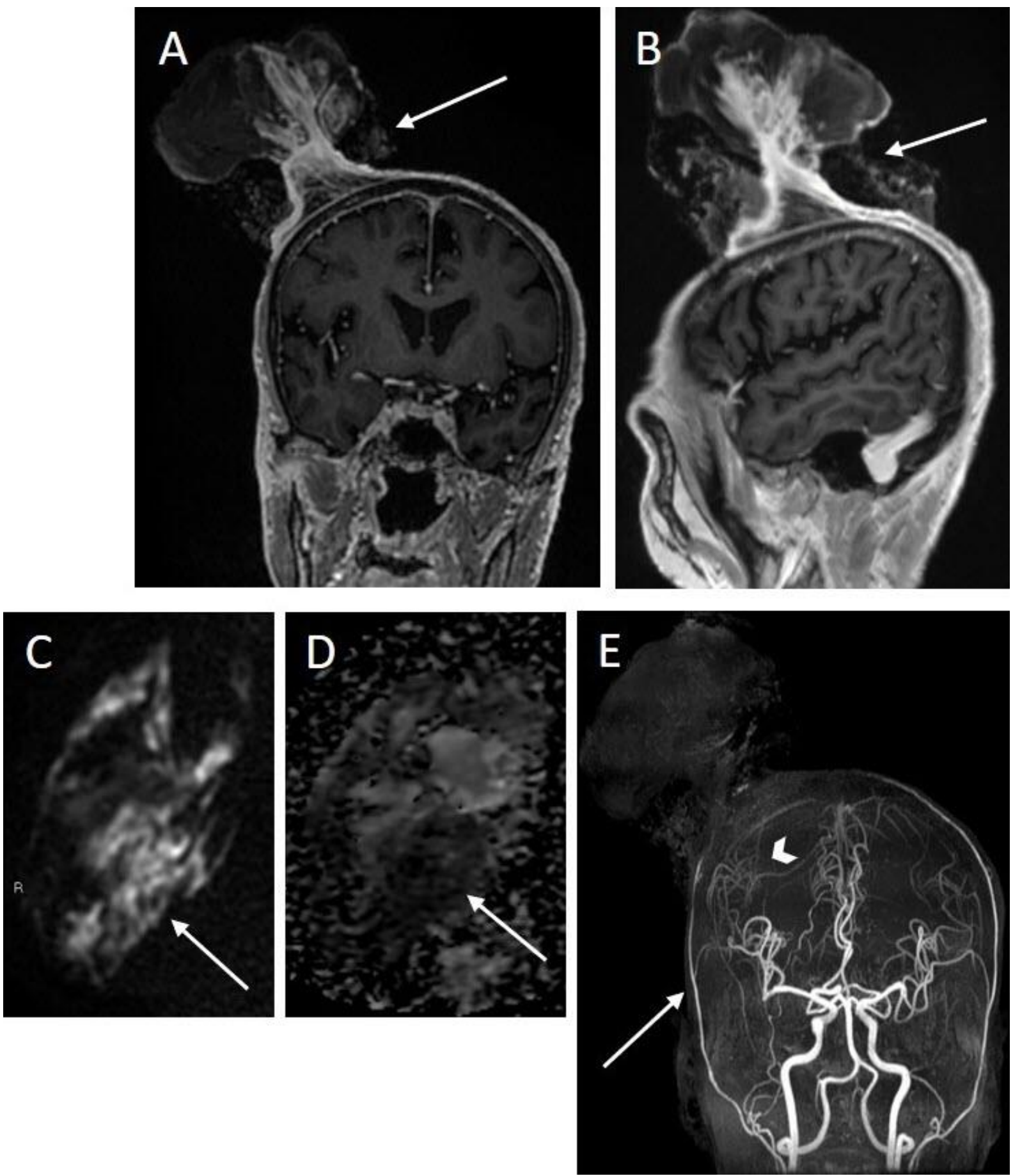

Figure 2: A 67-year-old man with a right parietal scalp tumor with histologically proven epithelioid sarcoma.

FINDINGS: Coronal (A) and sagittal (B) T1-weighted post-contrast MRI reveal avid enhancement in the center of the scalp mass (relative to the periphery) resembling the "stalk" of a "mushroom" (arrows). Axial Diffusion-weighted imaging (DWI) (C) and Apparent Diffusion Coefficient (ADC) (D) images reveal restricted diffusion within the center or "stalk" of the scalp mass (arrows).

Time of flight (TOF) MR angiogram (E) Maximal intensity projection (MIP) image in coronal plane reveals the scalp mass deriving the main blood supply from branches of the right occipital (arrowhead) and right superficial temporal (arrow) arteries.

TECHNIQUE: Post-contrast MRI of the 67-year-old man in coronal (A) and sagittal (B) planes. GE Medical system Signa Architect. Magnetic strength $=3$ Tesla. $\mathrm{TR}=23 \mathrm{~ms}$. TE $=7 \mathrm{~ms}$. Slice width $=1 \mathrm{~mm}$. Intravenous contrast $=$ Dotarem. Total amount contrast administered $=10 \mathrm{ml}$. DWI $(\mathrm{b}=1000)(\mathrm{C})$ and ADC (D) MRI in axial planes. Slice width $=4 \mathrm{~mm}$.

TOF-MRA (E) MIP of the 67-year-old man in coronal plane. GE Medical system Signa Architect. Magnetic strength = 3 Tesla. $\mathrm{TR}=23 \mathrm{~ms}$. TE $=7 \mathrm{~ms}$. Slice width $=1 \mathrm{~mm}$. No intravenous contrast was administered. 


\begin{tabular}{|c|c|}
\hline Etiology & - Loss of expression of tumour suppression gene INI1 (SMARCB1) \\
\hline Incidence & $\begin{array}{l}\text { - } 0.04 \text { per } 100,000 \text { for all epithelioid sarcoma } \\
\text { - Of which, } 3.2 \% \text { affects the scalp }\end{array}$ \\
\hline Gender Ratio & - 1.8 Male to every female \\
\hline Age predilection & $\begin{array}{l}\text { - Between } 1 \text { to } 80 \text { years of age } \\
\text { - Peak incidence at } 75 \text {-year-old }\end{array}$ \\
\hline Risk factors & $\begin{array}{l}\text { - Loss of expression of tumour suppression gene INI1 (SMARCB1) } \\
\text { - Local trauma }\end{array}$ \\
\hline Treatment & $\begin{array}{l}\text { - Local disease: Wide surgical resection and adjuvant radiotherapy; presurgical embolization to reduce } \\
\text { tumor vascularity; neo-adjuvant or adjuvant radiotherapy to reduce local recurrence. } \\
\text { - Distant metastases: Palliative treatment with Doxorubicin-based regimens }\end{array}$ \\
\hline Prognosis & $\begin{array}{l}\text { - Local disease: } 5 \text {-year survival of } 75 \% \\
\text { - Regional disease: } 5 \text {-year survival of } 49 \% \\
\text { - Distant metastases: } 1 \text {-year survival of } 46 \% \text {. } \\
\text { - 50\% develop distant metastases, especially to lungs, regional lymph nodes, and bones. } \\
\text { - 5-year recurrence rate: } 35 \%\end{array}$ \\
\hline $\begin{array}{l}\text { Findings on } \\
\text { imaging }\end{array}$ & $\begin{array}{l}\text { - MRI: T2 hyperintensity with restricted diffusion in the tumor center; peripheral heterogeneous T1 and T2 } \\
\text { intensities with areas of necrosis and/or ulceration; homogeneous central and patchy peripheral contrast } \\
\text { enhancement. } \\
\text { - Multilobulated morphology with irregular and ill-defined borders } \\
\text { - A vascular pedicle within the mass with blood supply from various arterial branches }\end{array}$ \\
\hline
\end{tabular}

Table 1: Summary table of epithelioid sarcoma.

$\mathrm{AFS}=$ Adult-type Fibrosarcoma, $\mathrm{BCCA}=$ Basal cell carcinoma, $\mathrm{CE}=$ contrast-enhanced, $\mathrm{CT}=$ computed tomography, $\mathrm{MRI}=\mathrm{Magnetic}$ resonance Imaging, MPNST= Malignant peripheral Nerve Sheath Tumor, MPTT= Malignant proliferating trichilemmal tumor, $\mathrm{SCCA}=$ squamous cell carcinoma 


\begin{tabular}{|c|c|c|c|c|}
\hline Diagnosis & $\begin{array}{l}\text { Age (years) } \\
\text { Sex }\end{array}$ & Common locations & Recurrence/ Metastasis & Imaging features of the scalp tumors \\
\hline $\begin{array}{l}\text { Epithelioid } \\
\text { sarcoma }\end{array}$ & $\begin{array}{l}\text { 17-60 } \\
\text { Men: Women } \\
1.5: 1.0\end{array}$ & $\begin{array}{l}\text { Extremities; rarely affect the } \\
\text { scalp. }\end{array}$ & $\begin{array}{l}\text { High-rate local recurrence and } \\
\text { distant metastases of } 35 \% \text { and } \\
50 \% \text {, respectively. Local } \\
\text { recurrence with lymphatic } \\
\text { invasion, skin ulceration, } \\
\text { necrosis, and bone erosion. }\end{array}$ & $\begin{array}{l}\text { MRI: T2 hyperintensity with restricted } \\
\text { diffusion in the tumor center; } \\
\text { heterogeneous T1 and T2-weighted } \\
\text { intensities with necrosis and ulceration. } \\
\text { Tumor shows homogeneous central and } \\
\text { patchy peripheral enhancement. }\end{array}$ \\
\hline Leiomyosarcoma & $\begin{array}{l}40-60 \\
\text { Men }\end{array}$ & $\begin{array}{l}2-3 \% \text { of all soft tissue } \\
\text { sarcomas }\end{array}$ & $\begin{array}{l}\text { Subcutaneous types had a } \\
\text { higher rate of local recurrence } \\
(50-70 \%) \text { and distant } \\
\text { metastases }(30-40 \%) \text {. }\end{array}$ & $\begin{array}{l}\text { CECT: Heterogeneous enhancement } \\
\text { with internal tumor necrosis and } \\
\text { calcifications. MRI: T1 hypointense and } \\
\text { mild T2 hyperintense lesion with } \\
\text { heterogeneous contrast enhancement }\end{array}$ \\
\hline MPNST & $\begin{array}{l}\text { 20-50 } \\
\text { Men with } \\
\text { NF1 }\end{array}$ & Head, neck, and extremities. & $\begin{array}{l}5-10 \% \text { of all soft tissue } \\
\text { sarcomas. High-rate relapses } \\
\text { despite active therapy. Poor } \\
\text { prognosis. }\end{array}$ & $\begin{array}{l}\text { Tumor causes scalloping and } \\
\text { remodeling of the adjacent skull bone. } \\
\text { MRI: T1 and T2 heterogeneous lesions } \\
\text { with restricted diffusion, and } \\
\text { heterogeneous enhancement. }\end{array}$ \\
\hline SCCA & $\begin{array}{l}65 \\
\text { Men }>\text { Women }\end{array}$ & $\begin{array}{l}\text { Chronic non-healing } \\
\text { ulceration in the face and } \\
\text { extremities; } 3-8 \% \text { SCCA } \\
\text { located in the scalp. }\end{array}$ & $\begin{array}{l}\text { Second most common skin } \\
\text { cancer after BCCA. Local } \\
\text { recurrence and distant } \\
\text { metastases in advanced stage }\end{array}$ & $\begin{array}{l}\text { MRI: T1 hypointense and } \\
\text { heterogeneously T2 hyperintense, with } \\
\text { homogeneous contrast enhancement. } \\
\text { Avid FDG uptake on PET/CT }\end{array}$ \\
\hline
\end{tabular}

Table 2: Differential diagnosis table for large malignant scalp tumors. 


\begin{tabular}{|c|c|c|c|c|c|c|c|c|}
\hline $\begin{array}{l}\text { Case } \\
\text { No. }\end{array}$ & $\begin{array}{l}\text { Age/ } \\
\text { sex }\end{array}$ & Position & $\begin{array}{l}\text { Tumor size } \\
\text { (cm) }\end{array}$ & $\begin{array}{l}\text { Radiological } \\
\text { features }\end{array}$ & Histological & Stage & Prognosis & Reference \\
\hline 1 & $34 / \mathrm{F}$ & $\begin{array}{l}\text { Temporal } \\
\text { space }\end{array}$ & $3.0 \times 2.5 \times 1.5$ & $\begin{array}{l}\text { Lobulated growing } \\
\text { mass }\end{array}$ & $\begin{array}{l}\text { EC; CN; pseudo } \\
\text { granulomatous }\end{array}$ & Local & $\mathrm{FD}, 18 \mathrm{mo}$ & Kim et al [9] \\
\hline 2 & $18 / \mathrm{M}$ & $\begin{array}{l}\text { Occipital } \\
\text { region }\end{array}$ & $2.7 \times 2 \times 1.5$ & $\mathrm{NM}$ & $\begin{array}{l}\text { EC; hemorrhage; } \\
\text { necrosis }\end{array}$ & LNM & - & $\begin{array}{l}\text { Gurwale et al } \\
\text { [30] }\end{array}$ \\
\hline 3 & $32 / \mathrm{M}$ & $\begin{array}{l}\text { Parietal } \\
\text { bone }\end{array}$ & - & $\begin{array}{l}\text { Mass; ulcers; BE; } \\
\text { high serum calcium } \\
\text { level }\end{array}$ & $\mathrm{EC} ; \mathrm{CN}$ & Local & - & $\begin{array}{l}\text { Tocco et al } \\
{[31]}\end{array}$ \\
\hline 4 & $21 / \mathrm{F}$ & $\begin{array}{l}\text { Supra- } \\
\text { auricular }\end{array}$ & $2 \times 4$ & $\mathrm{NM} ; \mathrm{BE}$ & $\begin{array}{l}\text { EC; CN; thin fibrous } \\
\text { septa; inflammation }\end{array}$ & LNM & $\begin{array}{l}\text { Recur in } \\
\text { 10th year }\end{array}$ & $\begin{array}{l}\text { Hanna et al } \\
{[32]}\end{array}$ \\
\hline 5 & $7 / \mathrm{M}$ & Scalp & $2.2 \times 2.5$ & NM; hemorrhage & $\begin{array}{l}\mathrm{SC} ; \mathrm{CN} \text {; thin fibrosis; } \\
\text { inflammation }\end{array}$ & Local & $\mathrm{FD}, 72 \mathrm{mo}$ & $\begin{array}{l}\text { Hanna et al } \\
{[32]}\end{array}$ \\
\hline 6 & $30 / \mathrm{F}$ & $\begin{array}{l}\text { Parieto- } \\
\text { occipital } \\
\text { scalp }\end{array}$ & $6 \times 5$ & NM; BE; hemorrhage & EC & Recurred & $\begin{array}{l}\text { Recur in } \\
\text { 3rd year }\end{array}$ & $\begin{array}{l}\text { Suwantemee } \\
\text { et al [33] }\end{array}$ \\
\hline 7 & $47 / \mathrm{M}$ & Scalp & - & Ulcer & SC; high grade & Local & - & $\begin{array}{l}\text { Skoog et al } \\
{[34]}\end{array}$ \\
\hline 8 & $7 / \mathrm{M}$ & Scalp & - & Not specific & $\begin{array}{l}\text { Central degeneration or } \\
\text { CN }\end{array}$ & Local & $\mathrm{FD}, 15 \mathrm{mo}$ & $\begin{array}{l}\text { Gross et al } \\
{[35]}\end{array}$ \\
\hline 9 & $1 / \mathrm{F}$ & Forehead & - & - & - & - & $\mathrm{FD}, 24 \mathrm{mo}$ & $\begin{array}{l}\text { Kodet et al } \\
{[36]}\end{array}$ \\
\hline 10 & $80 / \mathrm{M}$ & scalp & $1.5 \times 1 \times 0.8$ & Mass; ulcer & $\begin{array}{l}\mathrm{SC} ; \mathrm{CN} \text {; collagen } \\
\text { deposition; } \\
\text { inflammation; pseudo } \\
\text { granulomatous }\end{array}$ & Local & $\mathrm{FD}, 12 \mathrm{mo}$ & $\begin{array}{l}\text { Zhang et al } \\
\text { [6] }\end{array}$ \\
\hline $\begin{array}{l}11 \\
\text { (Cur } \\
\text { rent) }\end{array}$ & $67 / \mathrm{M}$ & $\begin{array}{l}\text { Parietal } \\
\text { scalp }\end{array}$ & $10 \times 5 \times 5$ & $\begin{array}{l}\text { Vascular, } \\
\text { hemorrhage } \\
\mathrm{CN}, \text { peripheral } \mathrm{Ca}+\end{array}$ & $\begin{array}{l}\text { Epithelioid cells } \\
\text { Sarcomatoid cells }\end{array}$ & Local & $\mathrm{FD}, 30 \mathrm{mo}$ & Current case \\
\hline
\end{tabular}

Table 3: Demographic, imaging, and histological data of 11 cases of primary epithelioid sarcoma of the scalp in the literature. $\mathrm{Ca}$ : calcification; M: male; F: female; NM: nodular mass; BE: bony erosion; CN: central necrosis; EC: dominated epithelioid tumor cells with abundant eosinophilic cytoplasm, vesicular nuclei and small prominent nucleoli; SC: dominated spindle or rhabdoid tumor cells with an apparent fascicular, fluvial or herringbone arrangement; LNM: Lymph node metastases; FD: free of disease.

Adapted from Zhang X-W, Deng Y-J, Zhou L, Deng H. Epithelioid sarcoma of the scalp: a case report and literature review. International journal of clinical and experimental pathology 2019;12(10):3908-3914.

\section{ABBREVIATIONS}

Apparent diffusion coefficient

AFS = Adult-type fibrosarcoma

$\mathrm{BCCA}=$ Basal cell carcinoma

CECT $=$ Contrast-enhanced computed tomography

$\mathrm{DD}=$ Differential diagnosis

DWI = Diffusion-weighted imaging

$\mathrm{ES}=$ Epithelioid sarcoma

LMS = Leiomyosarcoma

MPNST = Malignant peripheral nerve sheath tumor

MPTT $=$ Malignant proliferating trichilemmal tumor

SCCA = Poorly differentiated squamous cell carcinoma

$\mathrm{T} 1 \mathrm{~W}=\mathrm{T} 1$-weighted

TOF $=$ Time of flight

\section{KEYWORDS}

Angiosarcoma; epithelioid sarcoma; leiomyosarcoma; metastasis; radiotherapy

\section{Online access}

This publication is online available at: www.radiologycases.com/index.php/radiologycases/article/view/4326

\section{Peer discussion}

Discuss this manuscript in our protected discussion forum at: www.radiolopolis.com/forums/JRCR

\section{Interactivity}

This publication is available as an interactive article with scroll, window/level, magnify and more features. Available online at www.RadiologyCases.com

Published by EduRad

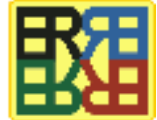

www.EduRad.org 